\title{
Antifungal Activity of Silver Nanoparticles Produced from Fungus, Penicillium fellutanum at Different $\mathrm{pH}$
}

Nida Tabassum Khan* and Namra Jameel

Department of Biotechnology, Faculty of Life Sciences and Informatics, Baluchistan University of Information Technology, Engineering and Management Sciences, Takatu Campus, Baluchistan, Pakistan

\begin{abstract}
Currently there are many approaches being engaged in the production of silver nanoparticles however these methods uses reducing agents such as sodium borohydride, hydrazine and organic passivators like thiourea, thiophenol, mercaptoacetate, etc. which are environmental pollutants and increases the overall cost of the process. Therefore biosynthesis of silver nanoparticle is now considered to be the most environmental friendly, cost effective method. The effect of different $\mathrm{pH}$ on the synthesis of silver nanoparticles was observed by altering the $\mathrm{pH}$ of the fungal filtrate using $0.1 \mathrm{~N}$ sodium hydroxide and $0.1 \mathrm{~N}$ hydrochloric acid. Rapid rate of silver nanoparticles were obtained at $\mathrm{pH} 8.0$ at $\lambda_{\max }$ of 440 . Produced silver nanoparticles were effective antifungal agents against Candida albicans, Candida glabrata and Candida tropicalis.
\end{abstract}

Keywords: Nanotechnology; Antifungal; Disc diffusion method; Candida albicans

\section{Introduction}

Acidification, conjugation, capping, mineralization, use of biological entities such as enzymes for catalysis and bioreduction, etc. are the other commonly employed modes used for the production of nanoparticles $[1,2]$. Nanoparticle synthesis can be either extracellular (nanoparticles are forming outside the cell) or intracellular formation (nanoparticles are forming inside the cell) depending on the location where these nanoparticles are formed however the exact mechanism is not understood completely [3-5].

Extracellular assembly of nanoparticles is more advantageous of the fact that it makes the downstream processing for the recovery and purification of the product much easier and does not require lysis of the host cell [6]. In addition according to Sharma et al. uses of nanoparticles will be better analysis if produced extracellularly [7]. Intracellular process of nanoparticle synthesis offers easy optimization to obtain definite size and shape of the nanoparticles but recovery and purification from the biomass is a tedious task it requires sophisticated equipment and expertise [6]. For example sulphate reductase contributes in sulphate ions reduction thus acting as a bioreducing agent and produces intracellular nanoparticles with semi conductive properties. While X-ray diffraction analysis depicts the nano crystalline nature of the nanoparticles.

Numerous publications have suggested that metallic nanoparticles have wide range of applications specifically in biomedical domains i.e. in nano medicine where they can be used in gene and drug delivery systems [8,9], in phagokinetic studies [10], in tissue engineering $[11,12]$, in tumor demolition through heating (hyperthermia) [13], as fluorescent biological labels $[14,15]$ in bio detection of pathogens [16] and in MRI contrast enhancement [17]. Among different nanoparticles, Nanosilver is the most mentioned nanomaterial and is evolving as the most effective nanoparticle with variety of applications [18]. Several examples stated in the literature that shows that the biosynthesis of silver nanoparticle can be achieved by the use of variety of organisms. For example extracellular production of stable silver nanoparticles using the fungus Aspergillus flavus has been reported by [18].

Similarly bacteria like Brevibacterium casei and Bacillus species $[19,20]$ are well known producers of silver nanoparticles. In addition plants such as Curry leaf (Murraya koenigii) was reported to synthesize spherical shape silver nanoparticles of uniform size of 10-25 $\mathrm{nm}$ [21]. In another study by Qian et al, Epicoccum nigrum, an endophytic fungi was found to synthesize AgNPs at varied temperature and $\mathrm{pH}$ [22].

Penicillium fellutanum, a fungus usually associated with decaying matter. Besides producing different antibiotics are well known producers of nanoparticles of silver [5,9]. In this work $\mathrm{AgNO}_{3}$ was fabricated at different $\mathrm{pH}$ from Penicillium fellutanum and evaluation of its antifungal activity was investigated against clinical pathogens.

\section{Materials and Methods}

Penicillium fellutanum, was grown in one liter of YM (yeast malt extract) broth prepared by dissolving peptone $(5 \mathrm{~g} / \mathrm{l})$, yeast extract (3 $\mathrm{g} / \mathrm{l})$, malt extract $(3 \mathrm{~g} / \mathrm{l})$, glucose $(10 \mathrm{~g} / \mathrm{l})$ in $1000 \mathrm{ml}$ of distilled water. The growth media was sterilized at $121^{\circ} \mathrm{C}$ for $20 \mathrm{~min}$ at $15 \mathrm{psi}$ (pound/ square inches). YM media was inoculated with Penicillium fellutanum and incubated for $120 \mathrm{~h}$ at room temperature on orbital shaker. After $120 \mathrm{~h}$ of growth the fungal filtrate was obtained by harvesting the fungal biomass using Whatman's filter paper no. 42 and saved for further use. The obtained cell free filtrate was then centrifuged at $10000 \mathrm{rpm}$ for 20 min.

$20 \mathrm{ml}$ of supernatant at different $\mathrm{pH}$ incubated with $90 \mathrm{ml}$ of 2 $\mathrm{mM}$ silver nitrate solution for $48 \mathrm{~h}$ in dark at room temperature. UV visible spectrometry absorbtion analysis recorded from $400 \mathrm{~nm}$ to 500 $\mathrm{nm}$ to determine $\lambda_{\max } . \mathrm{pH}$ of the supernatant was altered using $0.1 \mathrm{~N}$ sodium hydroxide and $0.1 \mathrm{~N}$ hydrochloric acid to adjust the $\mathrm{pH}$ to 5.0, 6.0, 7.0, 8.0 and 9.0, respectively. Five test tubes each containing $20 \mathrm{ml}$

*Corresponding author: Nida Tabassum Khan, Department of Biotechnology, Faculty of Life Sciences and Informatics, Baluchistan University of Information Technology, Engineering and Management Sciences, Takatu Campus, Baluchistan, Pakistan, Tel: 03368164903; E-mail: nidatabassumkhan@yahoo.com

Received September 05, 2016; Accepted September 30, 2016; Published October 08, 2016

Citation: Khan NT, Jameel N (2016) Antifungal Activity of Silver Nanoparticles Produced from Fungus, Penicillium fellutanum at Different $\mathrm{pH}$. J Microb Biochem Technol 8: 440-443. doi: 10.4172/1948-5948.1000322

Copyright: ( 2016 Khan NT, et al. This is an open-access article distributed under the terms of the Creative Commons Attribution License, which permits unrestricted use, distribution, and reproduction in any medium, provided the original author and source are credited. 
of supernatant at different $\mathrm{pH}$ incubated with $90 \mathrm{ml}$ of $2 \mathrm{mM}$ silver nitrate solution for $48 \mathrm{~h}$ in dark at room temperature. $1 \mathrm{ml}$ of the sample from each test tube was withdrawn after $48 \mathrm{~h}$ and subjected to UVvisible spectroscopy to measure its absorbance at a specific optimum wavelength to determine the optimum $\mathrm{pH}$ value of the extracellular aqueous media required for the production of silver nanocrystals. Distill water was used as reference.

Antifungal activity of silver nanoparticles was assessed using disc diffusion method carried on YM agar plates (dissolving yeast extract (3 $\mathrm{g} / \mathrm{l})$, glucose $(10 \mathrm{~g} / \mathrm{l})$, peptone $(5 \mathrm{~g} / \mathrm{l})$, malt extract $(3 \mathrm{~g} / \mathrm{l})$ and agar $(20$ $\mathrm{g} / \mathrm{l})$ in $1000 \mathrm{ml}$ of distilled water. The growth media was sterilized at $121^{\circ} \mathrm{C}$ for $20 \mathrm{~min}$ at $15 \mathrm{psi}$ (pound/square inches)) Before pouring 0.5 $\mathrm{ml}$ antibiotic ampicillin was added to the medium to inhibit bacterial contamination and $1 \mathrm{ml}$ of $10 \%$ sterilized tartaric acid solution to adjust $\mathrm{pH}$ of media (4.2-4.5).The surface of the agar was inoculated with the test pathogens such as Candida glabrata, Candida albicans and Candida tropicalis. Then sterile discs of size one centimeter was prepared and placed on agar surface impregnated with different concentration of silver nanoparticle solution $(20 \mu \mathrm{L}, 40 \mu \mathrm{L}, 60 \mu \mathrm{L}$ and $80 \mu \mathrm{L})$ in order to determine the dose dependent concentration .Incubation was done at $37^{\circ} \mathrm{C}$ for $48 \mathrm{~h}$, caliper was used to measure the diameter of the inhibition zone. Silver nitrate solution impregnated discs were used as control.

\section{Results and Discussion}

The confirmation of silver nanoparticles in the fungal filtrate incubated with silver nitrate solution for $48 \mathrm{hrs}$ was by means of visual change in the filtrate color from deep yellow to grey color (Figure 1) .change in color means that silver metal ions has been reduced by nitrate reductase, a NADPH-dependent enzymes involved in the synthesis of silver nanoparticles [23,24]. Bioreduction of silver ions were carried out by reduction-specific enzymes which resulted in the formation of silver metal ion aggregates which in turn form the desired silver nanoparticle [25].

UV visible spectra depicted maximum absorption at $440 \mathrm{~nm}$ (Figure 2). Similar results were mentioned by Duran et al. in his work [23]. Silver nanoparticles produce an intense absorption and scattering.

Five test tubes containing fungal filtrate incubated with silver nitrate at different $\mathrm{pH}$ displaying different color intensities indicating silver nanoparticles synthesis (Figure 3).

UV visible spectra obtained at different $\mathrm{pH}$ at $440 \mathrm{~nm}$ shows that maximum synthesis of silver nanoparticles occurred at alkaline $\mathrm{pH}$ of 8.0 (Figure 4). Thus, the synthesis of silver nanoparticles was greatly influenced by $\mathrm{pH}$ as confirmed by Riddin et al. that increased $\mathrm{pH}$ resulted in faster nanoparticle production [26]. The maximum peak at $\mathrm{pH} 8.0$ indicates the formation of nanoparticles with a size range between 10

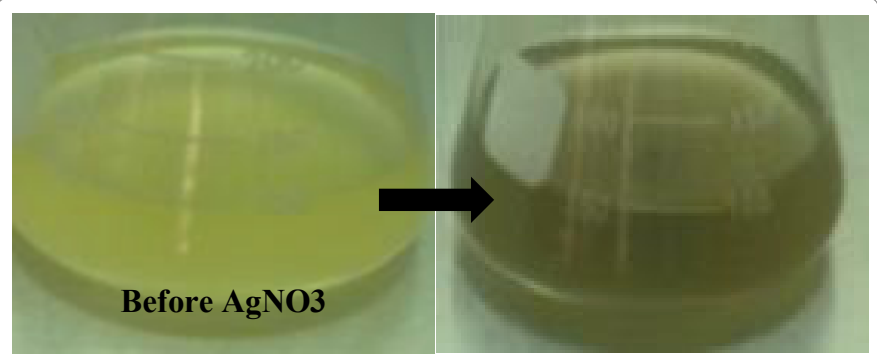

Figure 1: Appearance of grey brown color of the fungal filtrate after addition of silver nitrate solution.

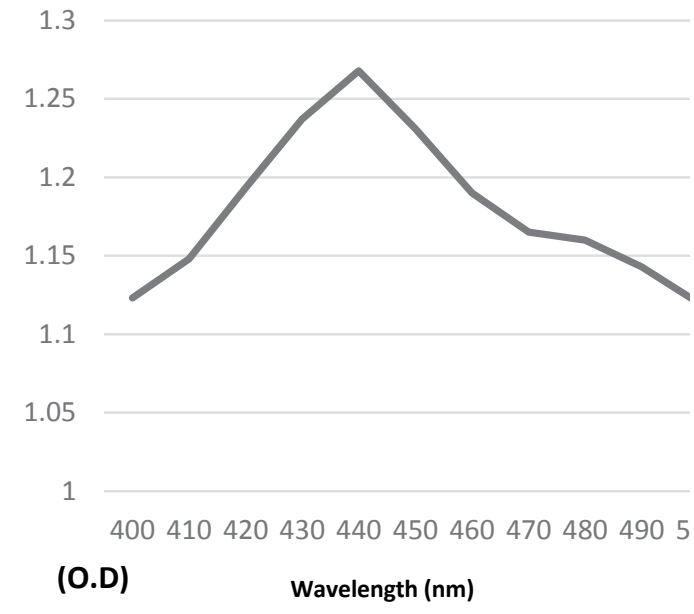

Figure 2: UV visible spectrum showing maximum absorbtion at $440 \mathrm{~nm}$.

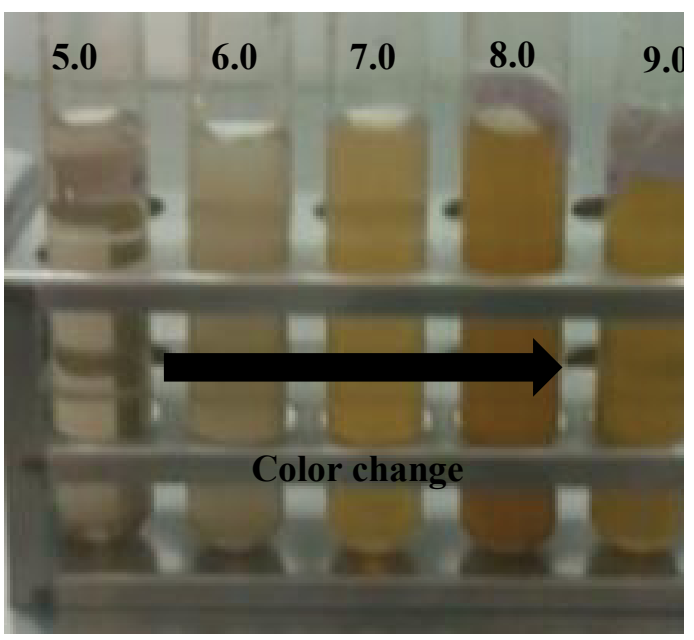

Figure 3: Color change in five test tubes at different $\mathrm{pH}$ indicating silver nanoparticles synthesis.

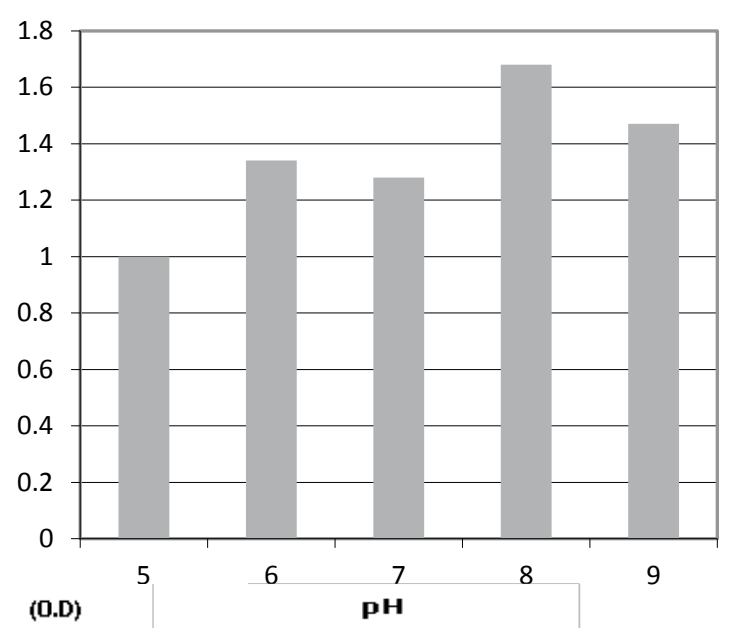

Figure 4: UV visible spectrum showing maximum silver nanoparticle synthesis at $\mathrm{pH}$ of 8.0 . 


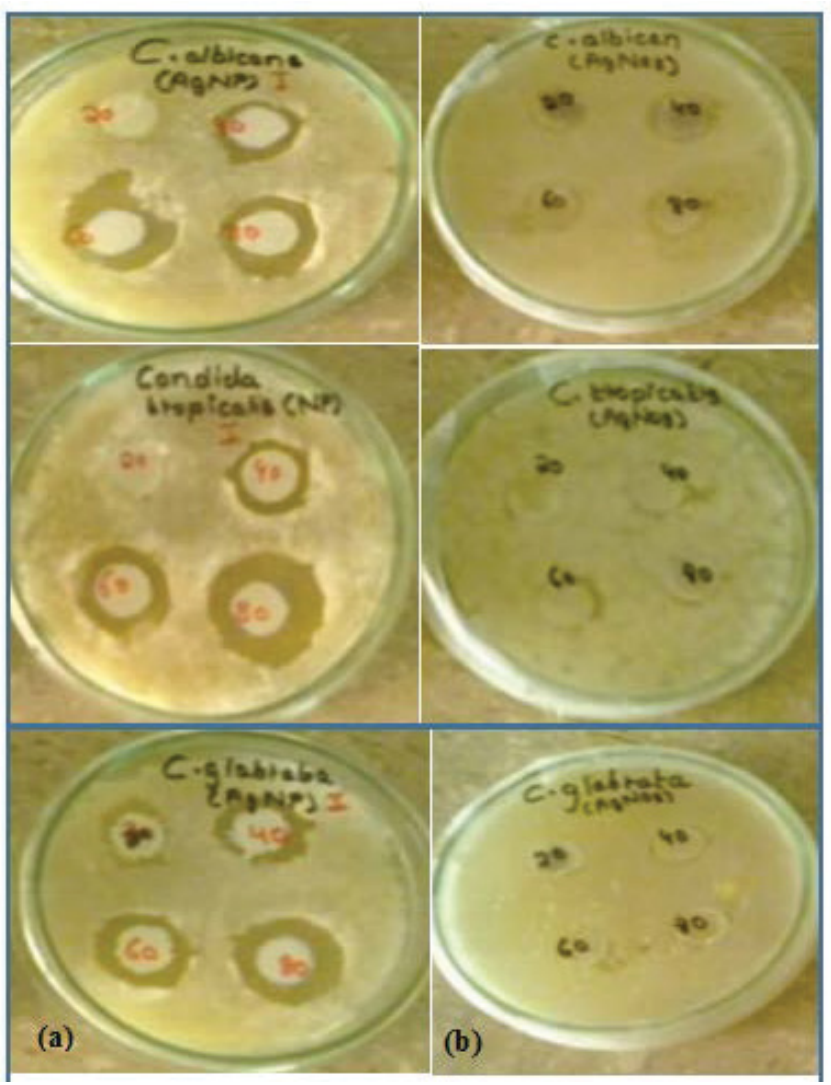

Figure 5: Antifungal activity of (a) silver nanoparticles synthesized at altered $\mathrm{pH}$ (b) silver nitrate (control).

to100 $\mathrm{nm}$ and showed maximum synthesis of silver nanoparticles. At alkaline medium number of functional groups available for silver binding increases thus facilitating higher number of Ag (I) to bind and subsequently results in the fabrication of large number of small sized silver nanoparticles with spherical morphology [27]. On the contrary decrease in $\mathrm{pH}$ to 5 did not show any peak. At low $\mathrm{pH}$, protein active sites gets affected and denatured and loses its activity thus aggregation of nanoparticles was seen [28].

Silver nanoparticles possess increased antifungal activity against Candida species [28-30]. Results obtained from disc diffusion method indicates Silver nanoparticles as effective antifungal agents against as Candida glabrata, Candida albicans and Candida tropicalis however no inhibition was observed in controls (Figure 5).

\section{Conclusion}

Silver Nanoparticles produced from fungus, Penicillium fellutanum at different $\mathrm{pH}$ were found to possess effective antifungal activities against clinical pathogens.

\section{References}

1. Wang Y, Du MH, Xu JK, Yang P, Du YK (2008) Biogenesis and optimisation of silver nanoparticles by the endophytic fungus Cladosporium sphaerospermum. Journal of Dispersion Science and Technology 29: 891-894.

2. Choudary BM, Madhi S, Chowdari NS, Kantam ML, Sreedhar B (2002) Layered double hydroxide supported nanopalladium catalyst for Heck-, Suzuki-, Sonogashira- and Stille-type coupling reactions of chloroarenes. Journal of the American Chemical Society 124: 14127-14136.

3. Ravindran TR, Arora AK, Balamurugan B, Mehta BR (2009) Materials research innovations 13: 32-34.
4. Liu SM, Liu FQ, Guo HQ, Zhang ZH, ZG (2000) Growth and characterization of InGaAs/InAIAs quantum cascade lasers. Solid State Communications 115 615-618.

5. Krishnaraj C, Jagan EG, Rajasekar S, Selvakumar P, Kalaichelvan PT (2010) Synthesis of silver nanoparticles using Acalypha indica leaf extracts and its antibacterial activity against water borne pathogens. Colloids and Surfaces B Biointerfaces 76: 50-56.

6. Naveen KSH, Kumar G, Karthik L, Rao KBV (2010) Extracellular biosynthesis of silver nanoparticles using the filamentous fungus Penicillium sp. Archives of Applied Science Research 2: 161-167.

7. Sharma VK, Yngard RA, Lin Y (2009) Silver nanoparticles: Green synthesis and their antimicrobial activities. Advances in Colloid and Interface Science 145: 83-96.

8. Tian F, Prina-Mello A, Estrada G, Beyerle A, Möller W, et al. (2008) A nove assay for the quantification of internalized nanoparticles in macrophages. Nanotoxicology 2: 232-242.

9. Cui D, Tian F, Coyer SR, Wang J, Pan B, et al (2007) Effects of antisenseMyc-conjugated single-walled carbon nanotubes on HL-60 cells. J Nanosci Nanotechnol 7: 1639-1646.

10. Parak WJ, Boudreau R, le Gros M, Gerion D, Zanchet D, et al. (2002) Cell motility and metastatic potential studies based on quantum dot imaging of phagokinetic tracks. Adv Mater 14: 882-885.

11. Ma J, Wong H, Kong LB, Peng KW (2003) Biomimetic processing of nanocrystallite bioactive apatite coating on titanium. Nanotechnology 14: 619.

12. De La Isla A, Brostow W, Bujard B, Estevez M, Rodriguez JR (2003) Nanohybrid scratch resistant coatings for teeth and bone viscoelasticity manifested in tribology. Mater Res Innov 7: 110-114

13. Shinkai M, Yanase M, Suzuki M, Honda H, Wakabayashi T, et al. (1999) Intracellular hyperthermia for cancer using magnetite cationic liposomes. Magn Magn Mater 194: 176-184.

14. Fadeel B, Garcia-Bennett AE (2010) Better safe than sorry: Understanding the toxicological properties of inorganic nanoparticles manufactured for biomedical applications. Adv Drug Deliv Rev 62: 362-374.

15. Chan WCW, Nie S (1998) Quantum dot bioconjugates for ultrasensitive nonisotopic detection. Science 281: 2016-2018.

16. Pantarotto D, Partidos CD, Hoebeke J, Brown F, Kramer ED, et al. (2003) Immunization with peptide-functionalized carbon nanotubes enhances virusspecific neutralizing antibody responses. Chem Biol 10: 961-966.

17. Weissleder R, Elizondo G, Wittenberg J, Rabito CA, Bengele HH (1990) Ultra small super paramagnetic iron oxide: Characterization of a new class of contrast agents for MR imaging. Radiology 175: 489-493.

18. Rai M, Yadav A, Gade A (2009) Silver nanoparticles as a new generation of antimicrobials. Biotechnology Advances 27: 76-83.

19. Kalimuthu K (2010) Biosynthesis of silver and gold nanoparticles using Brevibacterium casei. Colloids and Surfaces B: Biointerfaces 77: 257-262.

20. Babu GMM, Gunasekaran P (2009) Production and structural characterization of crystalline silver nanoparticles from Bacillus cereus isolate. Colloids Surf B Biointerfaces 74: 191-195s.

21. Christensen L, Vivekanandhan S, Misra M, Mohanty AK (2011) Biosynthesis of silver nanoparticles using Murraya koenigii (curry leaf): An investigation on the effect of broth concentration in reduction mechanism and particle size. Adv Mat Lett 2: 429-434.

22. Qian Y, Yu H, He D, Yang H, Wang W (2013) Biosynthesis of silver nanoparticles by the endophytic fungus Epicoccum nigrum and their activity against pathogenic fungi. Bioprocess and Biosystems Engineering 36: 1613-1619.

23. Durán N, Marcato PD, Alves OL, de Souza GIH, Esposito E (2005) Mechanistic aspects of biosynthesis of silver nanoparticles by several Fusarium oxysporum strains. J Nanobiotechnology 3: 1-8.

24. Vijayaraj D, Anarkali J, Rajathi K, Sridhar S (2012) Green synthesis and characterization of silver nanoparticles from the leaf extract of Aristolochia bracteata and its antimicrobial efficacy. International Journal of Nanomaterials and Biostructures 2: 11-15.

25. Mukherjee P, Ahmad A, Mandal D, Senapati S, Sainkar SR, et al. (2001) Fungus-mediated synthesis of silver nanoparticles and their immobilization 
Citation: Khan NT, Jameel N (2016) Antifungal Activity of Silver Nanoparticles Produced from Fungus, Penicillium fellutanum at Different pH. J Microb Biochem Technol 8: 440-443. doi: 10.4172/1948-5948.1000322

in the mycelial matrix: A novel biological approach to nanoparticle synthesis. Nano 1: 515-519.

26. Riddin TL, Gericke M, Whiteley CG (2006) Analysis of the inter- and extracellular formation of platinum nanoparticles by Fusarium oxysporum $\mathrm{F}$ sp. Iycopersici using response surface methodology. Nanotechnology 17: 3482- 348.

27. Sathishkumar M, Sneha K, Yun YS (2010) Immobilization of silver nanoparticles synthesized using Curcuma longa tuber powder and extract on cotton cloth for bactericidal activity. Journal of Bioresource Technology 101: 7958-7965.

28. Verma VC, Kharwar RN, Gange AC (2010) Biosynthesis of antimicrobial silver nanoparticles by the endophytic fungus Aspergillus clavatus. Nanomedicine 5 : 33-40.

29. Ray S, Sarkar S, Kundu S (2011) Extracellular biosynthesis of silver nanoparticles using the mycorrhizal mushroom Tricholoma crassum (Berk.) Sacc: Its antimicrobial activity against pathogenic bacteria and fungus, including multidrug resistant plant and human bacteria. Dig J Nanomater Bios 6: 1289-1299.

30. Gajbhiye M, Kesharwani J, Ingle A, Gade A, Rai M (2009) Fungus mediated synthesis of silver nanoparticles and their activity against pathogenic fungi in combination with fluconazole. Nanomed Nanotechnol Biol Med 5: 382-386. 